\title{
BANDING OF NESTLING BALD EAGLES IN YELLOWSTONE AND GRAND TETON NATIONAL PARKS AND VICINITY
}

\author{
Robert L. Eng \\ Alan Harmata \\ Kurt Alt \\ Department of Biology \\ Montana State University
}

\section{Objectives}

A significant population of nesting Bald Eagles (HaZiaeetus Zeucocphalus) occurs in and adjacent to Yellowstone National Park (YNP) and Grand Teton National Park (GTNP). Alt (1980) and Swenson (1975) located 30 Bald Eagle territories within an approximate $15,000 \mathrm{~km}^{2}$ area encompassing both parks and the surrounding area of southwestern Montana and northwestern Wyoming, designated here as the YellowstoneTeton area of Influence (YTAI). Although this population is probably essential in producing recruits for the remaining depressed western populations, little is known of the movements and dynamics of this population outside of the breeding season. As a result, a nestling banding project was initiated in the summer of 1979, and expanded to include colormarking in 1980, to determine post fledging movements and population dynamics of Bald Eagles produced in the YTAI. Through band recoveries and returns and resightings of colormarked eagles, attempts will be made to determine:

1) juvenile dispersal patterns

2) immature survival rates

3) longevity

4) wintering areas of YTAI Bald Eagles

5) mortality factors

6) migration routes

7) fidelity to the natal area in successive years

8) importance of the YTAI population in relation to producing recruits for other populations

9) assessment of banding activities on subsequent productivity. With adequate funding, the banding study should continue for at least 3 more years.

Methods

Nest site locations were compiled by Swenson (1975), Alt (1980) and by communication with local Game and Fish, National Park Service, and U.S. Forest Service personnel, Two aerial surveys were conducted during 1980 to determine reproductive activity of known sites and to search for new sites. Flights were conducted on 26 April and 16 June. Flights helped determine occupancy, activity, and productivity of nest sites, while allowing for the determination of desirable banding dates based on nestling age. All known Bald Eagles within the YTAl nest in trees. Tree climbing was accomplished by K. Alt with the help of a professional GTNP rescue climber, George Montopoli. 
All banded birds were banded with serially numbered USFWS "pop rivet" leg bands applied to one leg. Nestlings were also colormarked with plastic leg bands on the opposite leg. These bands were constructed from Lynn-Ply plastic, laminated green over white. Pieces of flat plastic $110 \mathrm{~mm} \times 32.5 \mathrm{~mm}$ were cut from a stock sheet. A white midline stripe was cut into the green base by a table saw set at the proper depth. Each piece was then placed in an oven at $300^{\circ} \mathrm{F}$ for 1.5 minutes, removed and wrapped around a $13 \mathrm{~mm}$ diameter wooden dowel, allowed to cool and removed. Bands were fitted to the eaglet by spreading the band, placing around the tarsus and the overlapping portions of the band cemented with Super Glue. Eagles so marked are obvious to concerned researchers looking at Bald Eagles but not obtrusive to the general public. Resighting requests were sent to appropriate individuals and agencies.

Culmen length and tarsus width of each banded eaglet were measured, These measurements are easily and quickly taken and beyond certain ages in some populations indicate sex. Vernier calipers were employed to secure each measurement.

Results

Thirty one (31) Bald Eagle territories were surveyed. Twenty six (26) eaglets were produced from 13 active territories and 17 were banded and colormarked. The Gallatin National Forest and one private individual denied access to 5 eagles in 3 nests. One territory thought to be inactive at banding time was later found to have produced 2 young (Oakleaf, personal communication).

Alteration of one nest would have been required to gain access to the nest proper so efforts were abandoned and an additional 2 young were not banded. Productivity data is summarized in Table 1.

One eaglet banded at Bridger Lake in the Bridger Teton National Forest has been recovered. Banded on 06-16-80, the eagle was found dead on 08-16-80 approximately $3.2 \mathrm{~km}$ north of the nest. The finder indicated that bird had been dead less than 1.5 weeks and the carcass had been scavenged by coyotes. The green and white leg band and USFWS band were intact and no abrasions were apparent on the legs.

\section{Conclusions}

The reproductive health of Bald Eagles in the YTAI appears to be improving. As total young and total young related to total occupied territories is the most instructive value when assessing reproductive health of eagles, comparison of these values over several years may indicate trends. Between 1972 and 1974 Swenson found average productivity to be .23 young per occupied pair in YNP with only 7 eagles fledged in 3 years, Between 1978 and 1980, 17 young were fledged for a productivity of .63 per occupied territory in YNP. 
Table 1. Productivity of Bald Eables in Grand Teton National Park, Yellowstone National Park and vicinity - 1980.

\begin{tabular}{lcccc}
\hline Productivity Criteria & YNP & GTNP & Vicinity & Total \\
\hline Territories observed & 15 & 4 & 12 & 31 \\
Territories occupied & 8 & 4 & $11^{a}$ & $23^{a}$ \\
Territories active & 8 & 3 & 11 & 22 \\
Successful nests & 1 & 1 & 11 & 13 \\
Number young fledged & 2 & 2 & 22 & 26 \\
Productivity (active) & .25 & .66 & 2.0 & 1.18 \\
Productivity (occupied) & .25 & .50 & 2.0 & 1.13 \\
\hline
\end{tabular}

a one additional nest not included in calculations had a known outcome but unknown occupancy. 
Banding activities in the YTAI do not appear to adversely effect productivity or welfare of Bald Eagles. Young per occupied territory, when banding operations were not in effect (1978) was .91 with 20 young produced. Combined productivity (young/occupied territory) for 1979 and 1980 when banding was underway, was higher and averaged .98 per occupied territory and 23.5 young fledged.

Banding did not appear to physically harm the bird found dead. No abrasions were present on the legs and bands were in original conditionapparently the bird did not try to remove them.

Banding operations and monitoring of Bald Eagle reproductive performance should be continued indefinitely. Nest visits required for banding have added insight into behavior, mortality, and productivity of YTAI Bald Eagles. Complete productivity data is available from 1972 to present and efforts should be made to continue long term monitoring. As several studies involving Bald Eagles are currently underway, the potential for resightings of colormarked Bald Eagles and recovery of bands is good.

\section{Literature Cited}

Alt, K. L. 1980. The status of the Bald Eagle and Osprey in the Grand Teton National Park - Yellowstone National Park complex. M.S. thes is Mont. St, Univ., Bozeman $89 \mathrm{pp}$.

Swenson, J. E. 1975. Ecology of the Bald Eagle and Osprey in Yellowstone National Park. M.S. thesis Mont. St. Univ., Bozeman $146 \mathrm{pp}$.

Personal Communication

Oakleaf, Robert Wyoming Game and Fish Dept. August 1980. 